\title{
INCREASING TRENDS OF TOURIST FLOWS FROM THE EUROPRAN COUNTRIES TO GEORGIA
}

\author{
Nino ABESADZE ${ }^{1}$, Rusudan KINKLADZE ${ }^{2}$, Nino PARESASHVILI ${ }^{3}$ \\ 1,3 Tbilisi State University,Tbilisi, Georgia \\ ${ }^{2}$ Georgian TechnicalUniversity, Tbilisi, Georgia
}

Corresponding author e-mail: ninka_abesadze@yahoo.com

\begin{abstract}
Tourism is developing in Georgia and it is the fact that the exemption of visa limitations has had an important impact on the growth of tourist flows. It may be assumed that significantly increased flows of EU citizens to Georgia in recent years are an immediate result of the liberal visa policy. Research methodology: methods of statistical observation, grouping and analysis were used in the research process. The number of total visitors to the country and that from the European Union increases annually. As the data of 2018 suggest, the visits to Georgia for $72.9 \%$ of the international visitors were recurring, while $27.1 \%$ of the visitors were on their first visit in Georgia. Visits from the EU are most common in the III quarter of the year, i.e. in summer. EU visitors are mostly from Poland, Germany, UK, France, Lithuania and other countries. Most visitors are of the 26-35 age group. The most visited place is Tbilisi. The visits from the EU show a generally increasing trend, with the greatest increase fixed in 2018 as compared to the previous year; men dominate among the international visitors. The EU countries show a similar regularity; as to the age categories, 31-50 age group dominates among the international visitors and 26-65 age group dominates among the EU visitors; a leading country with the largest number of visits from the EU is Poland; the degree of satisfaction is high, with only $1.7 \%$ of the international inbound visitors being discontent.
\end{abstract}

Keywords: Tourist, EU, Trend, Statistics, Analysis

JEL Classification: C1

\section{INTRODUCTION}

Georgia is a country very rich in natural beauty, with an extensive history and culture. Georgia has also many natural heritage products, such as the mountain resorts such as Borjomi, Abastumani, Tskaltubo, Sairme and so on. People often visit these places not only for the unique nature, but for the exceptional air and water quality, which some believe can cure different deceases. Another popular destination is the sea resort Ureki with its course dark sands with magnetic properties which are also said to treat health problems. The country also has winter resorts such as Gudauri and Bakuriani, with abundant annual snowfalls, which are popular destination or tourists and skiers, as well as natural gorges and delightful waterfalls, attracting local and international trekkers and nature-lovers. This is why year after year the number of foreign visitors to Georgia is growing (Abesadze, Mindorashvili \& Paresashvili, 2017). The fact is that tourism needs more support to use its full potential. One main promoting factor can be developing tourism destination management, including understanding importance of stakeholders and their cooperation. So it is important to estimate events in a tourism field, detect trends and determine statistical rules. For this purpose we need objective information that requires perfect adaptation of international techniques of statistical accounting of tourism and practical implementation of these techniques on-site (Abesadze, Mindorashvili \& Paresashvili, 
2016). Today, in the modern era of economic development, tourism is a very important source of development and economic growth. Therefore, its improvement plays a crucial role and is considered to be the the pre-condition for developing Georgian economy and reaching high economic growth rate.

Today the trend of tourism development in Georgia is the systematic increase of tourist flows from the EU to Georgia. Although the same growth rates are not observed as in the tourist flows of neighboring countries, but the number of tourists arriving from EU countries is increasing every year.This is confirmed by statistics.

\section{METHODOLOGY}

Methods of statistical observation, grouping and analysis were used in the research process. The main source of information was the data of National Statistics Office and the National Tourism Administration. for visual effects we used a graphic method.

\section{RESULTS}

Tourism in Georgia is one of the priorities for country's economic development. Georgia has a lot to offer visitors because of its great tourism potential (Abesadze, 2018). In the modern way of understanding, tourism for Georgia is more than just its social and economic impact. Tourism combines the transport, service and social spheres, which, due to its multifaceted variety, have a significant impact on the country's economic development (EEAS, 2017).

The development of tourism as one of the specific sectors of the national economy requires the development of right state policy. Its specificity is that the economy and tourism of the country itself tightly interact with each other. There is a direct link between them, namely, the growth of the country's high economic potential and stability is a prerequisite for the rapid development of the tourism business, and vice versa. Tourism development also strengthens and enhances the economic potential of the country (DCFTA, 2016).

This is indisputable as the increase in the number of tourists brings in additional foreign currency to the country, the number of employees increases, the infrastructure and vehicles improve, the quality of service improves, new business opportunities develope and most importantly, the unique opportunity for regional development creates. It should be noted that tourism is a very important issue for the country, especially if the country is rich in natural resources and important, interesting cultural heritage. Georgia has always been in the spotlight of tourists in this regard and many foreigners visit our country today as well (Heinrich-BöllStiftung, 2012). However, it does not mean that every challenge has been handled. Problems in the tourism sector truly exist, solving these problems are the part of country's economic policy. Therefore, analysis of the factors and problems which affect tourism is significant.

Based on the studies, the following factors are hindering tourism development in Georgia: tourism infrastructure; quality of service; high price level; lack of tourism product diversity low country awareness and inadequate image; sustainable development and state support; lack of coordination, etc. The long-term success of tourism depends on the development of the mentioned areas. The removal of visa restrictions has had a significant impact on the growth of tourist flows. Georgia has launched its own liberal visa policy since June 1, 2006, when the „Georgian Law on the Legal Status of Foreigners"came into force. Under this law, citizens of the European Union and many other countries have been waived visa restrictions and were allowed to enter and move freely within Georgia for 90 days. (Ministry of foreign affairs of Georgia, 2016). Later, the 90-day limit has increased to 360 days and today citizens of more 
than 80 countries can freely enter the country a.nd stay in Georgia for about a year without additional documents or permits (European Initiative - Liberal Academy Tbilisi, 2019 ). That is why it will be interesting to look at the dynamics of EU citizens entering Georgia in Georgia for two periods: before 2006 and after 2006 till today. As 2006 is an important year because of Georgia's unilateral visa liberalization with the European Union.

It should be noted that, Georgia's government and society should temper their expectations regarding full membership in the Union anytime soon and instead concentrate on more immediate goals such as: completing Georgia's integration into the EU single market by implementing labor mobility with the EU; and establishing and deepening institutional relationships with EU military and security structures (Lebanidze, 2017). All this will contribute to the further development of tourism.

According to official data of the Ministry of Internal Affairs (2019), the total number of citizens coming to Georgia from the EU member states in 2004-2011 is 653 344, the highest of which is distributed in the following countries: Germany - 109 457, Greece - 94 581, Great Britain - 74 258, France - 50 625, Bulgaria - 47 902. In this case, Cyprus (1774), Malta (615), and Luxemburg (615) have the lowest rates. In 2004-2006, most of the tourists came from European Union countries (Germany, Great Britain, Greece, Bulgaria and France). In all five countries, the rate was slightly but still increasing from 2004 to 2005 . The number of visitors has increased dramatically since 2006, compared to 2005. The same is true of other EU member states. Georgia has slightly negative dynamics with only two countries: Luxembourg (53 citizens in 2005, 26 citizens in 2007) and Slovenia (260 citizens in 2005, 244 citizens in 2007). With two out of the five countries named in 2007-2011 - Greece and France - there is a clear upward trend, while a decline for Germany, the UK and Bulgaria is also noticeable.

The number of citizens arriving in Georgia during the mentioned period, in the end, is still much higher than the data of the previous period. In 2004-2005, 82044 people entered Georgia from the European Union, while in 2007-2008, due to one-way isa liberalization, the number of people entering Georgia doubled, to 172096 . The number of visitors increased by $76.0 \%$ in 2004-2007 in comparison with 2005. A similar trend is maintained in the coming years. . Overall, the number of visitors from all EU countries has significantly increased in Georgia. For example, if in 2005 there were 48508 persons, in 2011 the number increased to 136975 , or almost three times. The significant increase in the flow of EU citizens in Georgia in recent years has been the result the result of liberal visa policy. As it is known, on March 8, 2017, the Official Journal of the European Union published a change to the EU Council Regulation, according to which Georgia has moved to the list of countries having visa-free regime with the EU. Consequently, as of March 28, 2017, Georgian citizens holding a biometric passport are able to travel to the EU / Schengen countries without a visa (Ministry of Internal Affairs, 2019).

It is interesting to see how the dynamics of tourist arrivals and departures from Georgia to the EU have changed since visa liberalization.

For the statistical analysis of tourism flows, the data from three different sources have been examined: data from the Ministry of Internal Affairs (2019), Georgian National Tourism Administration (GNTA) and National Statistics Office of Georgia (2019). The number of tourists arriving from the EU is generally characterized by an upward trend. In 2011-2018, the number of tourists increased by an average of $19 \%$. In 2018 alone $36 \%$ more tourists came from EU countries than in the previous year. 
Table 1. Dynamics of tourists from EU entering Georgia in 2011-2018

(National Statistics Office of Georgia, 2019)

\begin{tabular}{|l|c|c|c|c|c|c|c|c|}
\hline & $\mathbf{2 0 1 1}$ & $\mathbf{2 0 1 2}$ & $\mathbf{2 0 1 3}$ & $\mathbf{2 0 1 4}$ & $\mathbf{2 0 1 5}$ & $\mathbf{2 0 1 6}$ & $\mathbf{2 0 1 7}$ & $\mathbf{2 0 1 8}$ \\
\hline All & 1832,8 & 2459,8 & 2884,3 & 2938,9 & 3011,7 & 3297,3 & 4069,4 & 4756,8 \\
\hline $\begin{array}{l}\text { EU countries } \\
\text { (thousand) }\end{array}$ & 108,5 & 136,4 & 163,9 & 183,9 & 198,2 & 219,5 & 269,9 & 368,1 \\
\hline
\end{tabular}

However, data from years of analysis show that absolute growth is not characterized by a growth trend for all years (See Fig. 1).

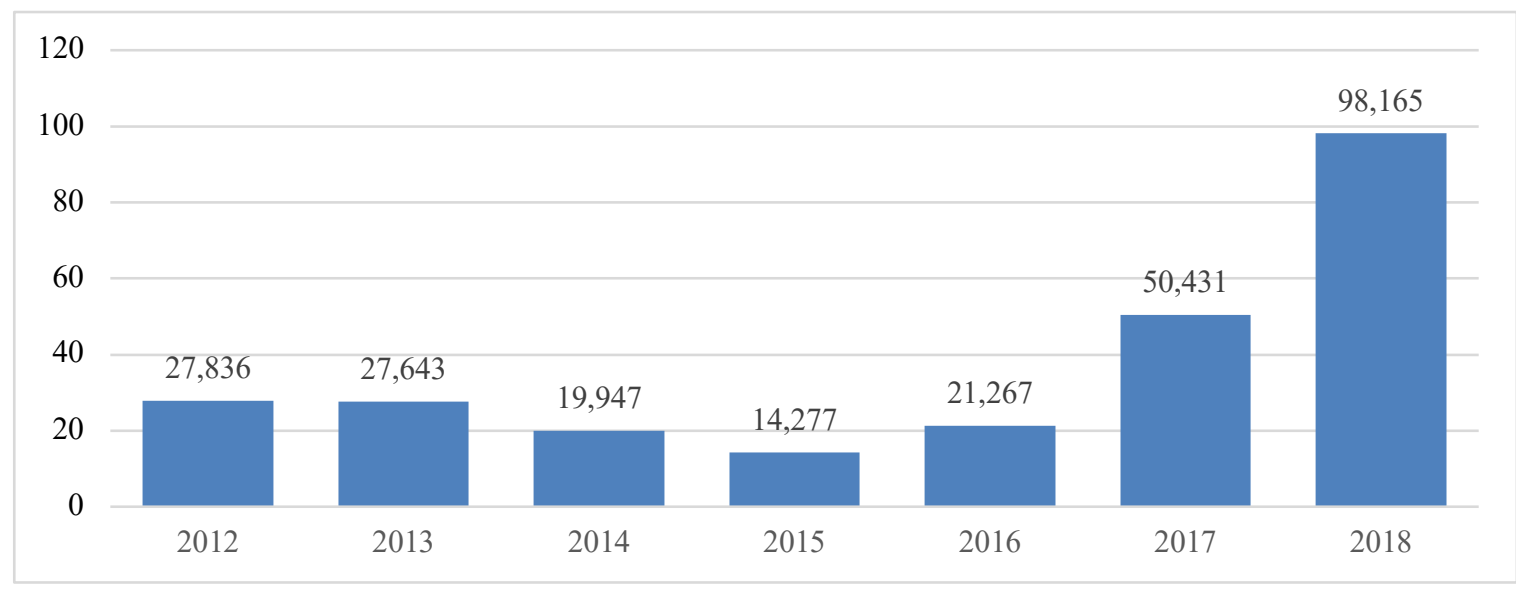

Fig. 1. The dynamics of absolute increase of tourists from EU entering Georgia in 2011-2018 (National Statistics Office of Georgia, 2019).

The highest growth rate was $136.4 \%$ in 2018 , as expected. Whereas the lowest $107.8 \%$ was in 2015 . The growth rate is $28.6 \%$. The range of growth rate was $28.6 \%$.

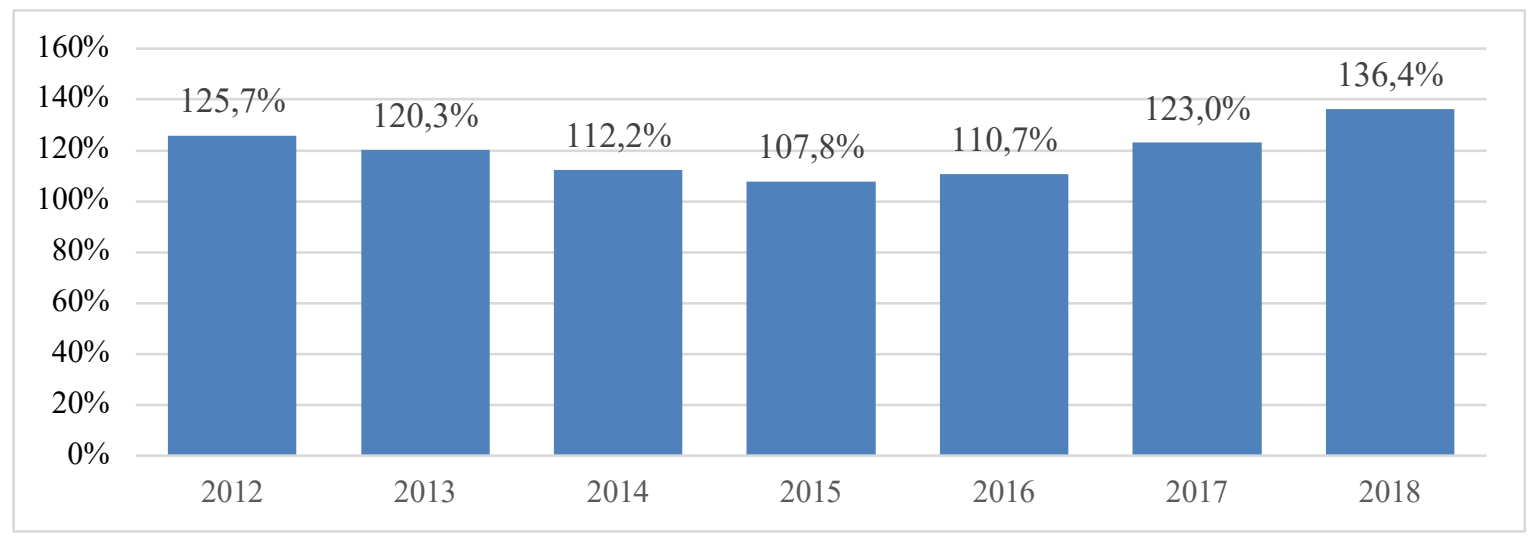

Fig. 2. Dynamics of growth rates of tourists from EU entering Georgia in 2011-2018

(National Statistics Office of Georgia, 2019).

The number of visitors from the EU increases by 37,000 annually during the study period.

\section{What is the demographic profile of the visitors?}

In 2018, the number of men coming from the EU exceeds the number of women. Similar trends have been observed in all EU countries except Belgium, Italy and Luxembourg, where on the contrary, the number of women exceeds that of men. The majority of visitors coming 
from the EU in 2018 are 26-35 years old, which is $21.7 \%$ of the total EU visitors, followed by $19.4 \% 36-45$ years old. It is very interesting that a significant share of visitors over the age of 65 is $-11.1 \%$, while the smallest share is in the category of $18-25$ year olds, whose share is only 6.6\% (Fig.3.).

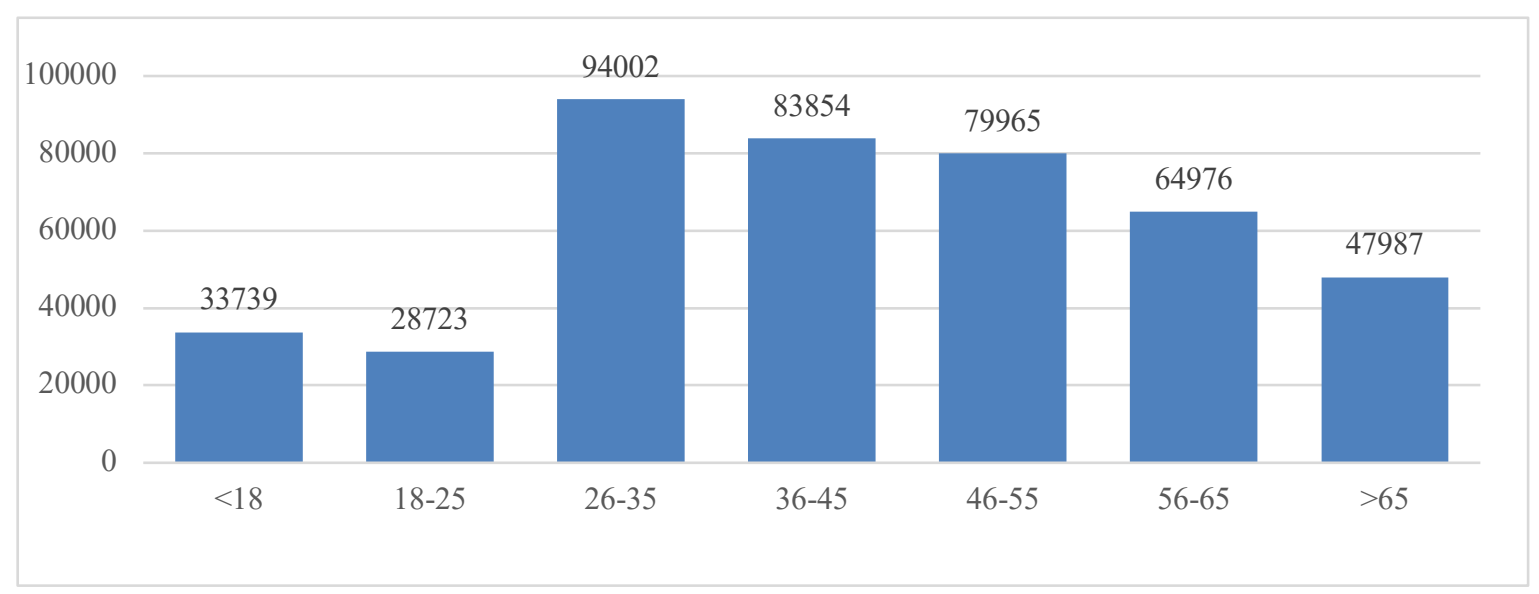

Fig. 3. Tourists from EU in 2018 by age (National Statistics Office of Georgia, 2019).

Let's consider the table below in detail by EU countries, with 28 countries in the 20112018 dynamics that are ranked in the top ten by 2018. Regarding the geographical structure of visitors, in 2018, visitors from the European Union mainly came from Poland (65 361 people) from Germany - 61 422, from the United Kingdom - 28 148, from France - 20 491, from Lithuania - 18425.

In 2017, the same trends were observed, except for Lithuania, which was replaced by Greece (Fig.4.).

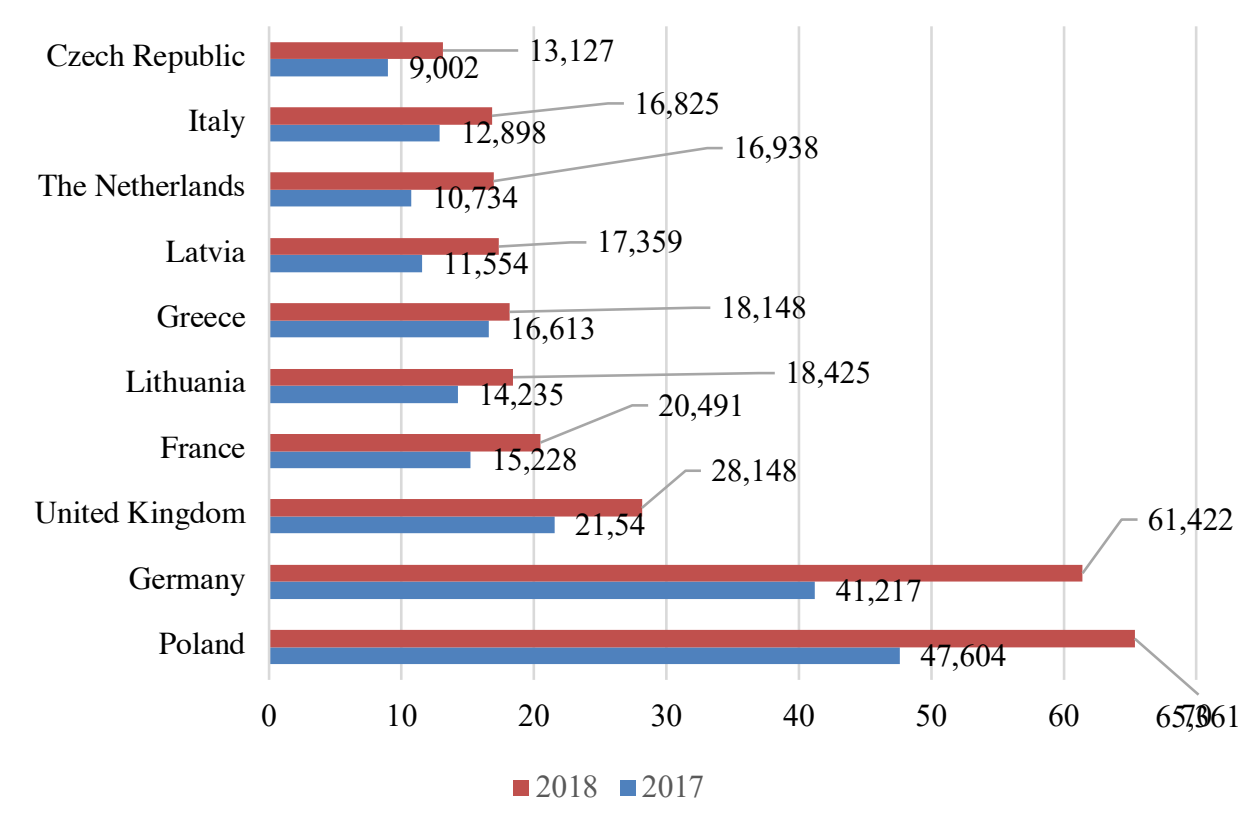

Fig. 4. Geographical structure of the visitors (National Statistics Office of Georgia, 2019). 
Germany has always been at the forefront in 2011-2018, however, the number of tourists coming from Poland is truly interesting, which has significantly increased. In 2011, their number was 10 906, and in 2018 it reached 65361 and outstripped Germany.

EU visits are mainly in the III quarter, respectively in the summer, with the least visits in the I quarter - during the winter. The number of visits in the III quarter increased by $40 \%$ compared to the same period last year ( Fig.5).

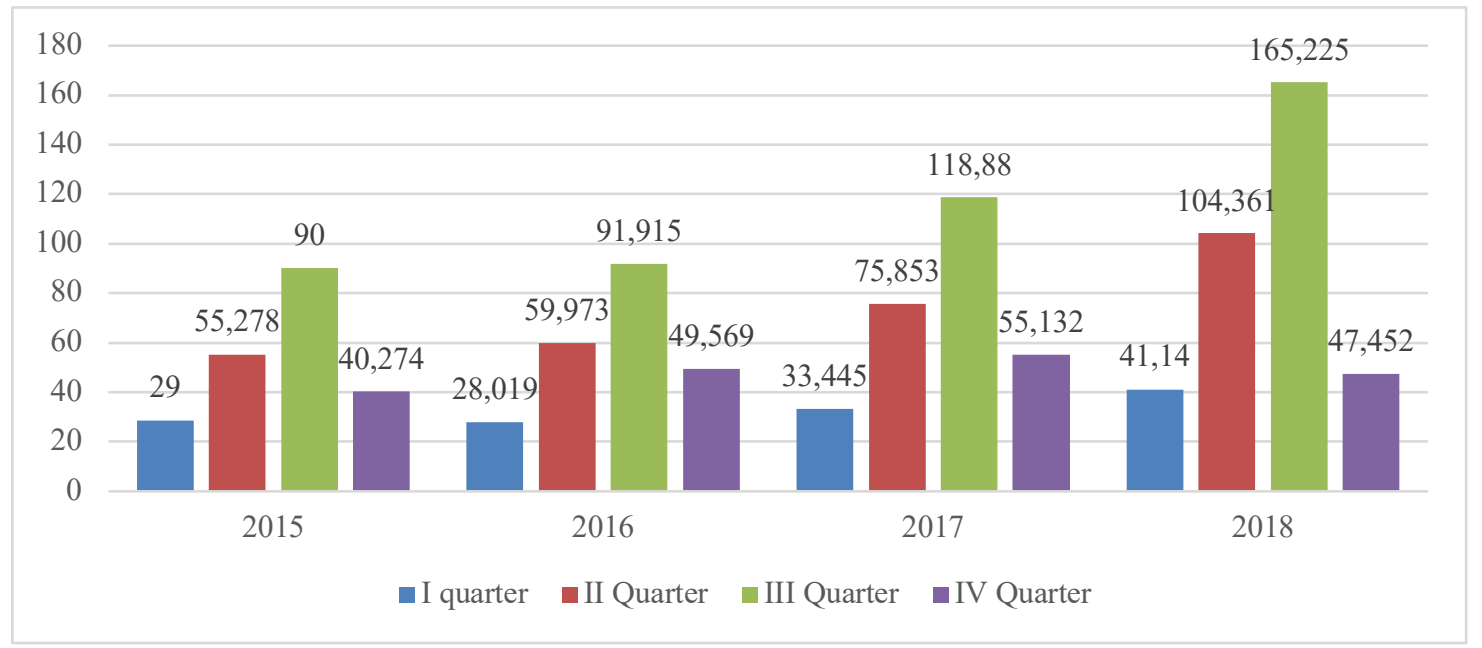

Fig. 5. Visits from EU by Quarters (National Statistics Office of Georgia, 2019).

It should be noted that in $2018,72.9 \%$ of international visits were repeat visits and $27.1 \%$ for the first time. This indicates that tourists are satisfied with their visit to Georgia and that is why there is a large share of repeat visits. As a result, the quality of tourist satisfaction is high, with only $1.7 \%$ of international visitors being dissatisfied with visiting Georgia.

Which regions are the most attractive for tourists anyway? Visitors mainly visit Tbilisi, Adjara, Mtskheta-Mtianeti, Kvemo Kartli, Kakheti, Samtskhe-Javakheti, Imereti.

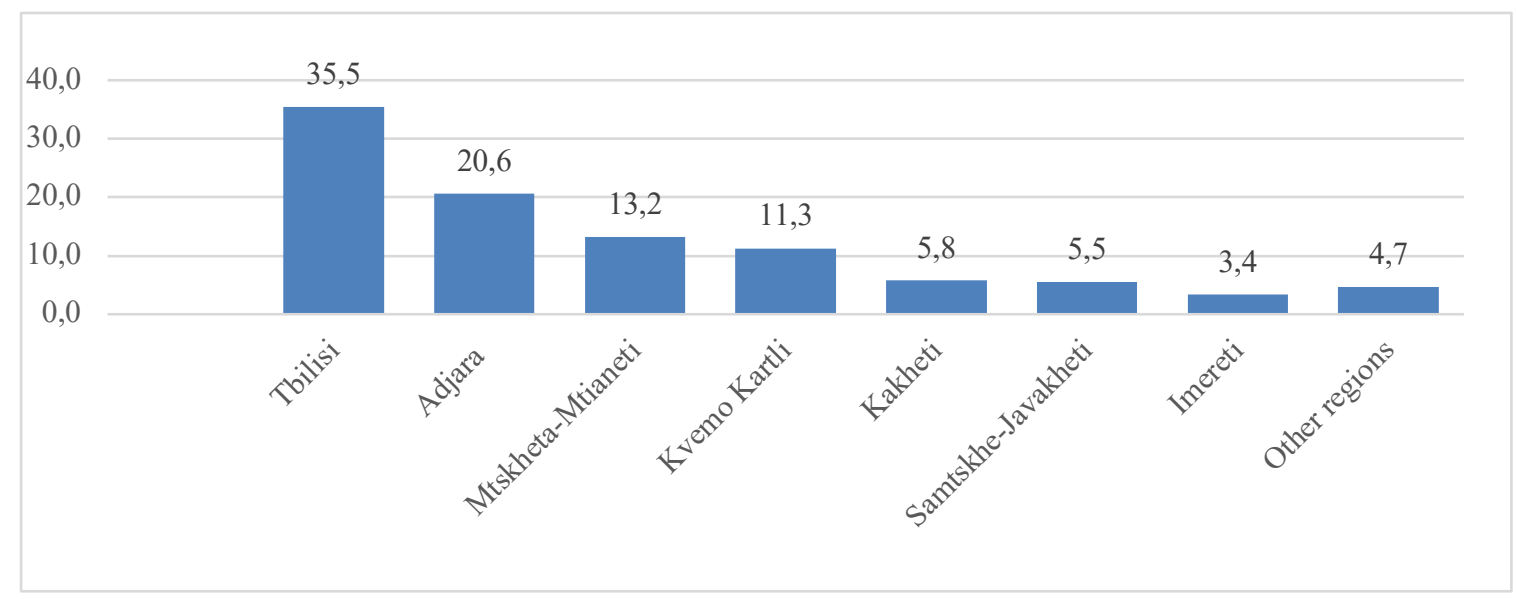

Fig. 6. Distribution of tourists by places of interest

(National Statistics Office of Georgia, 2019).

The Association Agreement "recognizes" Georgia as an Eastern European country and its European aspirations and Recognizes the European choice (GRASS, 2017). Therefore, we expect the increase in tourist arrivals. 


\section{CONCLUSION}

- The number of international visitors has reached its historic maximum in 2018.

- In general, tourists come to Georgia mainly by land. However, the number of air entrants is increasing every year.

- The main part of visits by air arrives in Tbilisi International Airport.

- The number of visitors to the country as a whole and from the EU states increases every year, and therefore the percentage of EU visitors to the total number of visitors is increasing.

- In $2018,72.9 \%$ of international visits were repeat visits and $27.1 \%$ for the first time. This indicates that tourists are happy to visit Georgia and that is why there is a large share of repeat visits.

- Among international visitors, male gender prevails over female, a similar pattern is depicted in EU countries.

- The age group leading in the international visitors is between 31-50, whereas from the EU is $26-65$.

- Poland is the leader in visits from EU.

- Satisfaction level is high: Only $1.7 \%$ of international visitors are dissatisfied.

\section{REFERENCES}

Abesadze, N. (2018). Global Indices and Tourism Development in Georgia. Scientific publication Teaching Statistics and Statistical Research in Georgia, 22-23.

Georgian National Tourism Administration. (2016). Tourism Development Prospects in Georgia and World Experience, Tbilisi.

Abesadze, N., Mindorashvili, M., Paresashvili,N. (2017). Georgia Case: Tourism Expenses od International Visitors on the Basis of Growing Attractiveness. WASET International Journal Economics and Management Engineering, 11(11), 2633-2638. Retrieved from https://pdfs.semanticscholar.org/e2ab/a09af4e2f7d88146d265d6a921cc26b535c2.pdf

Abesadze, N., Mindorashvili, M., Paresashvili, N. (2016). Statistical Data of Differentiation of Tourist Expenses. The Collection of scientific proceedings, Financial and credit activity: problems and prospect, 2(21), 248257.

DCFTA. (2016). Georgia and EU. Short Guide. Retrieved July 28, 2019, from http://www.dcfta.gov.ge/public/filemanager/publications/pub2.pdf

Department of Economic and Social Affairs Statistics Division. (2010). International Recommendations for Tourism Statistics 2008. Retrieved July 22, 2019, from: http: https://unstats.un.org/unsd/publication/seriesm/seriesm_83revle.pdf

EU and Georgia: Partnership for Youth. (2019) Retrieved September 30, 2019, from https://www.euneighbours.eu/ka/east/stay-informed/publications/evrokavshiri-da-sakartvelo-partnioruliurtiertoba

EEAS. (2017). EU-Georgia Relations: Challenges and Opportunities in a New Global Context. European External Action Service (EEAS). Retrieved September $30, \quad 2019$, from https://eeas.europa.eu/delegations/georgia_ka/19773

Heinrich-Böll-Stiftung. (2012). Georgia and its future in Europe. Retrieved September 29, 2019, from https://ge.boell.org/en/2012/03/01/georgia-and-its-future-europe

Georgia and the EU: Convergence through Reforms. (2018). Retrieved September 30, 2019, from https://www.radiotavisupleba.ge/a/sakartvelo-evrokavshiri/29018930.html

Georgia Visa Liberalization - Prospects and Parallels. (2017). Retrieved September 30, 2019, from http://regionaldialogue.com/visa-lib/. 
GRASS. (2017). Georgia's way to EU membership. Georgia's Reforms Associates (GRASS). Retrieved September 30, 2019, from https://grass.org.ge/wp-content/uploads/2017/05/Road-Map-to-the-EUMembership.-16.05.17.pdf

European Initiative - Liberal Academy Tbilisi. (2019). Visa Facilitation and Readmission: Prospects for VisaFree Travel - p.8. Retrieved July 25, 2019, from http://www.ei-lat.ge/?lang=en-GB

Lebanidze, B. (2017). Georgia's European Integration: What will happen after the Eastern Partnership? Georgian Institute of Politics, 6, 1-19. https://doi.org/10.13140/RG.2.2.26107.62246

Methodological manual for tourism statistics, Eurostat. (2014). Retrieved July 22, 2019, from:https://ec.europa.eu/eurostat/documents/3859598/6454997/KS-GQ-14-013-EN-N.pdf/166605aa-c99040c4-b9f7-59c297154277

Ministry of foreign affairs of Georgia. (2016). Timeline of important events in Georgia-EU relations. Retrieved July 20, 2019, from http:/www.mfa.gov.ge/

Ministry of internal affairs of Georgia. (2019). Retrieved July 20, 2019, from https://police.ge/en/search?q=STATISTIC+DATA+ON+THE+NUMBER+OF+VISITORS+ENTERING+G EORGIA

National Statistics Office of Georgia. (2019). Retrieved July 18, 2019, from https://www.geostat.ge/en

Paresashvili, N. (2014). Major Tasks of Ecotourism Management in Georgia. Journal Procedia-Social and Behavioral Sciences, 156, 170-173.

\section{AUTHORS' SHORT BIOGRAPHY}

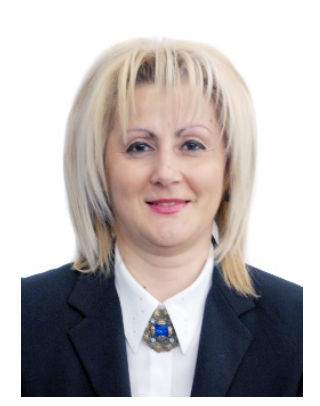

Nino Abesadze, Academic Doctor of Economics. Graduated from Tbilisi State University, 1987

In 1993, she defended her doctoral dissertation. In 1993-2006, she was a lecturer at Tbilisi State University, and since 2006 she is Associate Professor of Ivane Javakhishvili Tbilisi State University. She is the author of 138 scientific papers. Her field of study is tourism statistics, gender statistics, social statistics, business statistics.

Address:13, Amagleba str. Tbilisi, Georgia

Email: ninka abesadze@yahoo.com; nino.abesadze@tsu.ge

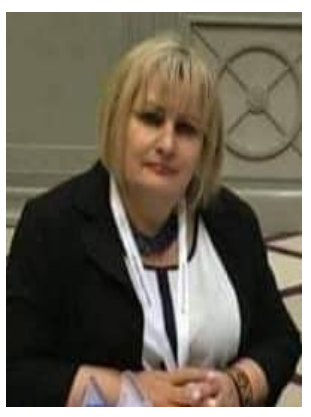

Rusudan Kinkladze Academic Doctor of Economics. Graduated from Tbilisi State University, 1986

In 2008, she defended her doctoral dissertation. In 1993-2009 she was a lecturer at Tbilisi State University, and since 2009 she is Associate Professor of Georgian Technical University.She is the author of 110 scientific papers. Her field of study is tourism statistics, labor market statistics, social statistics, business statistics.

Address: 5 Nutsubidze str. Home 3. Tbilisi, Georgia

Email: rusudan1103@yahoo.com

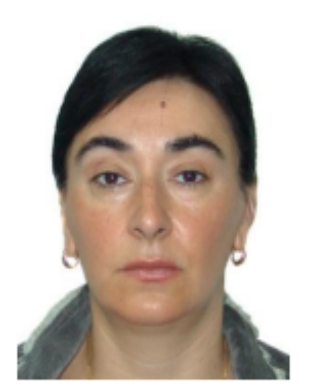

Nino Paresashvili Academic Doctor of of Economics. Graduated from Tbilisi State University, 1987.

In 2008, she defended her doctoral dissertation. In 1991-2006 she was a lecturer at Tbilisi State University, 2006 she was an assistant Professor and since 2014 she is Associate Professor and also since 2015 she is depute dean of Economics and Business faculty of Ivane Javakhishvili Tbilisi State

University. She is the author of 83 scientific papers. Her field of study is management, human management, conflict management, organization behaviour, cross-cultural management.

Address: Kavtaradze str.N 70 , Tbilisi, Georgia.

Email: nino.paresashvili@tsu.ge 